\title{
The presence of polymorphisms in genes controlling neurotransmitter metabolism and disease prognosis in patients with prostate cancer: a possible link with schizophrenia
}

\author{
Gennady M. Zharinov ${ }^{1, *}$, Sergei E. Khalchitsky2,*, Alexandre Loktionov ${ }^{3}$, Marina V. \\ Sogoyan ${ }^{2}$, Yulia V. Khutoryanskaya ${ }^{4}$, Natalia Yu. Neklasova ${ }^{1}$, Oleg A. Bogomolov ${ }^{1}$, \\ Ilya V. Smirnov ${ }^{1}$, Marina P. Samoilovich ${ }^{1}$, Vladimir N. Skakun ${ }^{5}$, Sergei V. \\ Vissarionov ${ }^{2}$ and Vladimir N. Anisimov ${ }^{6}$ \\ ${ }^{1}$ A.M. Granov Russian Research Center for Radiology and Surgical Technologies of the Ministry of Health of the Russian \\ Federation, Pesochny, St. Petersburg, 197758, Russia \\ ${ }^{2} \mathrm{H}$. Turner National Medical Research Center for Children's Orthopedics and Trauma Surgery of the Ministry of Health of the \\ Russian Federation, Pushkin, St. Petersburg, 196603, Russia \\ ${ }^{3}$ DiagNodus Ltd, Babraham Research Campus, Cambridge, CB22 3AT, United Kingdom \\ ${ }^{4}$ St. Petersburg State Pediatric Medical University of the Ministry of Health of the Russian Federation, St. Petersburg, 194100, Russia \\ ${ }^{5}$ Yaroslav-the-Wise Novgorod State University of the Ministry of Science and Higher Education of the Russian Federation, \\ Veliky Novgorod, 173003, Russia \\ ${ }^{6}$ N.N. Petrov National Medical Research Center of Oncology, Pesochny, St. Petersburg, 197758, Russia \\ *These authors contributed equally to this work \\ Correspondence to: Vladimir N. Anisimov, email: aging@mail.ru \\ Keywords: prostate cancer; prostate-specific antigen; disease prognosis; neurotransmitters metabolism genes; psychiatric disorders \\ Received: February 11,2021 Accepted: March 08, $2021 \quad$ Published: March 30, 2021 \\ Copyright: ( 2021 Zharinov et al. This is an open access article distributed under the terms of the Creative Commons Attribution License \\ (CC BY 3.0), which permits unrestricted use, distribution, and reproduction in any medium, provided the original author and source are credited.
}

\section{ABSTRACT}

Polymorphisms of neurotransmitter metabolism genes were studied in patients with prostate cancer (PC) characterized by either reduced or extended serum prostatespecific antigen doubling time (PSADT) corresponding to unfavorable and favorable disease prognosis respectively. The 'unfavorable prognosis' group (40 cases) was defined by PSADT $\leq 2$ months, whereas patients in the 'favorable prognosis' group (67 cases) had PSADT $\geq \mathbf{3 0}$ months. The following gene polymorphisms known to be associated with neuropsychiatric disorders were investigated: a) the STin2 VNTR in the serotonin transporter SLC6A4 gene; b) the 30-bp VNTR in the monoamine oxidase A MAOA gene; c) the Val158Met polymorphism in the catechol-ortho-methyltransferase COMT gene; d) the promoter region C-521T polymorphism and the 48 VNTR in the third exon of the dopamine receptor DRD4 gene.

The STin2 12R/10R variant of the SLC6A4 gene (OR $=2.278 ; 95 \% \mathrm{CI}=0.953-$ $5.444)$ and the $-521 \mathrm{~T} / \mathrm{T}$ homozygosity of the DRD4 gene (OR $=1.579 ; 95 \% \mathrm{CI}=$ 0.663-3.761) tended to be overrepresented in PC patients with unfavorable disease prognosis. These gene variants are regarded as protective against schizophrenia, and the observed trend may be directly related to a reduced PC risk described for schizophrenia patients. These results warrant further investigation of the potential role of neurotransmitter metabolism gene polymorphisms in PC pathogenesis.

\section{INTRODUCTION}

The importance of complex networks of heterotypic interactions between multiple distinct cell types (both malignant and normal) and regulatory circuits has now become widely recognized. It is also accepted that under certain (still poorly understood) circumstances these diverse components may assemble and collaborate to produce neoplasms and lead to cancer progression $[1,2]$. These advances provoked a gradual paradigm 
shift regarding views on carcinogenesis in general. The traditional tumor-centric view focused exclusively on malignant cell populations has largely been replaced with a concept of tumor microenvironment (TME), the latter being regarded as a "dynamic interaction arena in which tumor cells interact with the extracellular matrix (ECM), resident and recruited cells, and soluble factors" [3]. Indeed, tumor-TME crosstalk involves such major phenomena as metabolism profiling, a range of immune responses (including inflammation), ECM remodeling, and angiogenesis; concerted action of these components modulates tumor growth [2-7]. However, the current fixation of many investigators on the TME may create a bias of exaggerating the importance of immediate surroundings of neoplastic cells in affecting cancer progression, whereas more remote layers of tumor environment within the organism are sometimes overlooked [8].

It is well established that cancer is a disease driven by multiple genetic changes occurring in the malignant cells [1]. At the same time, numerous polymorphic gene variants commonly present in the human genome were shown to mildly influence cancer pathogenesis and tumor progression [9, 10], and it appears that that genetic variability may contribute to occasionally detected associations between malignancies and non-oncological conditions. One of such associations was highlighted by repeated observations of liaisons between emotional stress, depression and chronic psychiatric disorders with the risk of cancer development [11-16]. Although there is a general consensus that chronic stress and depression tend to result in an impairment of the immune responses and might facilitate cancer initiation and progression [11, $14,15]$, the risk of developing some cancers appeared to be decreased in patients with schizophrenia $[13,16]$. Remarkably, a significantly reduced risk of developing prostate cancer (PC) was consistently reported for men suffering from this severe condition [13, 16-18].

$\mathrm{PC}$ is not only the second most common cancer in men [19], but this is also a condition characterized by a wide variation of severity that ranges from indolent to highly aggressive disease [20]. The latter feature of PC makes tumor growth monitoring a very important prerequisite for successful disease management, and repeated measurement of the concentration of a blood biomarker of PC, prostate-specific antigen (PSA), is generally accepted as an important prognostic tool for routinely monitoring patients with this condition [21$25]$. Over the past 25 years, more than 6,000 PC cases were observed and treated at the Russian Scientific Center of Radiology and Surgical Technologies (RSCRST - St Petersburg, Russia). The results of the primary examination and consequent follow-up of these patients allowed creating the "Database of Prostate Cancer Patients" registered in Russia in 2016 [26]. The information on PSA concentration dynamics before treatment was available for about 2,500 of the cases included in the database, making it possible to determine the doubling time of PSA concentration (PSADT) that allows assessing tumor growth rate and aggressivity, serving as a valuable prognostic criterion [23-25]. It is also remarkable that the psychological state of the PC patients included in the database appeared to correlate with the PSADT and disease prognosis [27], thus corroborating observations of other authors mentioned before [11-18].

It is well established that many principal traits of an individual's temperament, character, and emotions are genetically determined, being controlled by the products of neurotransmitter-encoding genes that are often highly polymorphic. Polymorphisms present in the genes controlling mediators of the serotonin and dopamine systems are known to modulate predispositions to aggressiveness, depression, bipolar disorder, schizophrenia, suicidal and deviant behavior in general [28-32]. The presence of such polymorphisms may entail gene expression changes that often result in modifications of important metabolic patterns that can potentially interfere with neoplasia development, but this intriguing area remains poorly investigated.

It was noted above that psychiatric disorders may be associated with a seriously altered PC risk, but little is known about possible influences of patients' genetic background both on this phenomenon and on disease prognosis when PC is already present. The aim of this small pilot study was to compare the presence of common polymorphic variants of a few genes encoding neurotransmitters in PC patients with the 'polar' variants of disease prognosis defined by either very low or very high PSADT values.

\section{RESULTS}

\section{Clinical characteristics of study participants}

General clinical characteristics of PC patients included in the study are presented in Table 1 . The table clearly shows that the men in the unfavorable prognosis group were characterized by significantly higher $(P<$ $0.001)$ Gleason scores, significantly higher $(P<0.001)$ initial PSA concentrations, and significantly lower $(P<$ $0.001)$ PSADT values. It is also evident that men with low PSADT values (favorable prognosis group) had a much longer pre-treatment period $(P<0.001)$, sometimes reaching a few years. At the same time, no age difference between the groups could be detected.

\section{Patient genotyping results}

\section{SLC6A4 gene}

The presence of polymorphic variants of the SLC6A4 gene encoding serotonin transporter is known 
Table 1: Clinical characteristics of PC patients included in the study

\begin{tabular}{|c|c|c|c|}
\hline \multirow[b]{2}{*}{ Index } & \multicolumn{2}{|c|}{ Disease prognosis (according to PSADT) } & \multirow[t]{2}{*}{$P$-value } \\
\hline & $\begin{array}{l}\text { Unfavorable } \\
\text { (low PSADT) }\end{array}$ & $\begin{array}{c}\text { Favorable } \\
\text { (high PSADT) }\end{array}$ & \\
\hline Number of patients & 40 & 67 & - \\
\hline $\begin{array}{l}\text { Age at the time of } \\
\text { diagnosis, years } \\
\text { Median }\left(\mathrm{IQR}^{*}\right)\end{array}$ & $66.4(61.5-70.7)$ & $68.0(63.0-72.6)$ & $>0.05$ \\
\hline $\begin{array}{c}\text { Gleason score } \\
\text { Mean }\left(95 \% \mathrm{CI}^{* *}\right)\end{array}$ & $7.7(7.5-8.0)$ & $6.4(6.2-6.5)$ & $<0.001$ \\
\hline $\begin{array}{l}\text { Initial PSA, ng/ml Median } \\
\text { (IQR) }\end{array}$ & $109.0(41.6-328.9)$ & $12.9(9.6-18.7)$ & $<0.001$ \\
\hline $\begin{array}{c}\text { Duration of baseline PSA } \\
\text { history before treatment, } \\
\text { months }\end{array}$ & $2.0(1.0-3.0)$ & $59.0(29.0-110.5)$ & $<0.001$ \\
\hline $\begin{array}{l}\text { Number of initial } \\
\text { analyzes for } \\
\text { PSA } \\
\text { before treatment }\end{array}$ & $2.0(2.0-2.0)$ & $10.0(4.0-20.0)$ & $<0.001$ \\
\hline $\begin{array}{l}\text { PSADT, month, } \\
\text { Median (IQR) }\end{array}$ & $1.4(0.8-2.0)$ & $77.1(49.6-119.0)$ & $<0.001$ \\
\hline
\end{tabular}

${ }^{*} \mathrm{IQR}$ - interquartile range. ${ }^{* *} \mathrm{CI}$ - confidence interval.

to be associated with psychiatric disorders [28, 29]. Table 2 shows the results of STin2 VNTR (variable number of tandem repeats) genotyping in the second intron of this gene in PC patients with unfavorable and favorable disease prognosis. The STin2 polymorphism is a region of variable repeats in intron 2 and includes two major alleles "STin2.10" and "STin2.12", which correspond to 10 or 12 repeats (10R or $12 \mathrm{R}$ ) of $17 \mathrm{bp}$ respectively. In addition, there are less frequent "STin 2.7" and "STin2.9" alleles corresponding to seven and nine repeats respectively. Table 2 demonstrates that differences between the compared groups were observed for the genotypes $12 \mathrm{R} / 12 \mathrm{R}, 12 \mathrm{R} / 10 \mathrm{R}, 10 \mathrm{R} / 10 \mathrm{R}$, as well as for the homozygosity, and heterozygosity at this locus in general. In particular, the $12 \mathrm{R} / 12 \mathrm{R}$ and $10 \mathrm{R} / 10 \mathrm{R}$ variants and homozygosity at the locus appeared to be associated with a better PC prognosis, whereas the $12 \mathrm{R} / 10 \mathrm{R}$ genotype and heterozygosity at the locus were associated with a poorer PC prognosis. Although these differences between the groups failed to reach statistical significance, the results for the $12 \mathrm{R} / 10 \mathrm{R}$ variant, homozygosity and heterozygosity were only marginally non-significant. It should also be noted that in some cases genotyping could not be performed due to poor sample quality, thus the number of analyzed patients was strictly limited.

\section{$M A O A$ gene}

The MAOA gene encoding monoamine oxidase A (MAOA) and located on the short arm of the $\mathrm{X}$ chromosome contains a VNTR of 30bp with 2, 3, 3.5, 4, or 5 repeated copies [33]. The most common variants are alleles with three and four repeats, the latter one being responsible for a higher activity of the enzyme [33]. Conversely, the presence of the allele with three repeats leads to a decrease in MAOA activity resulting in an increased serotonin level in the synapses, which was reported to increase the risk of aggression and antisocial behavior [34].

The results of $M A O A$ genotyping presented in Table 3 show that only variants with 3 or 4 repeats (3R or $4 \mathrm{R}$ ) could be detected in the investigated groups of patients. In patients with an unfavorable $\mathrm{PC}$ prognosis, the $3 \mathrm{R}$ variant tended to be slightly more common $(\mathrm{OR}=$ 1.582), however the difference between the groups failed to reach statistical significance.

\section{COMT gene}

The COMT gene encodes catechol-Omethyltransferase (COMT), an enzyme that breaks down dopamine in the prefrontal cortex of the human brain. The Val158Met polymorphism of the gene that leads to a decreased COMT activity in $\mathrm{Met}^{158}$ allele bearers (especially A/A homozygotes) was reported to be linked with neuropsychiatric conditions, such as alcohol dependence, bipolar disorder, schizophrenia [35-37]. The results presented in Table 4 show that the heterozygosity (G/A genotype) for this locus is slightly overrepresented in patients with unfavorable PC prognosis. In contrast, the homozygosity at the locus and, especially, the presence of the G/G genotype seemed to be weakly associated with a better prognosis of the disease. At the same time, PC prognosis did not depend on the presence of the genotypes 
Table 2: Genotype frequencies for the STin 2 VNTR polymorphism of the $S L C 6 A 4$ gene in groups of PC patients defined as 'polar opposites' prognostically

\begin{tabular}{|c|c|c|c|c|c|c|}
\hline \multirow{3}{*}{$\begin{array}{c}\text { Genotypes for } \\
\text { SLC6A4 STin2 VNTR } \\
\text { polymorphism, number } \\
\text { of } 17 \text { bp repeats }\end{array}$} & \multicolumn{4}{|c|}{ Disease prognosis (according to PSADT) } & \multirow{3}{*}{$\begin{array}{l}\text { Odds Ratio } \\
\left(95 \% \mathrm{CI}^{*}\right)\end{array}$} & \multirow{3}{*}{$P$-value } \\
\hline & \multicolumn{2}{|c|}{$\begin{array}{c}\text { Unfavorable } \\
\text { (low PSADT) }\end{array}$} & \multicolumn{2}{|c|}{$\begin{array}{c}\text { Favorable } \\
\text { (high PSADT) }\end{array}$} & & \\
\hline & $n$ & $\%$ & $\bar{n}$ & $\%$ & & \\
\hline $12 \mathrm{R} / 12 \mathrm{R}$ & 4 & 11.76 & 13 & 22.03 & $0.472(0.140-1.584)$ & 0.224 \\
\hline $12 \mathrm{R} / 10 \mathrm{R}$ & 17 & 50,00 & 18 & 30.51 & $2.278(0.953-5.444)$ & 0.064 \\
\hline $12 \mathrm{R} / 9 \mathrm{R}$ & 1 & 2.94 & 1 & 1.69 & $1.758(0.106-29.036)$ & 0.693 \\
\hline $12 \mathrm{R} / 7 \mathrm{R}$ & 0 & 0 & 1 & 1.69 & $0.565(0.022-14.263)$ & 0.729 \\
\hline $10 \mathrm{R} / 10 \mathrm{R}$ & 6 & 17.65 & 16 & 27.12 & $0.576(0.201-1.649)$ & 0.304 \\
\hline $10 \mathrm{R} / 9 \mathrm{R}$ & 5 & 14.71 & 7 & 11.86 & $1.281(0.373-4.401)$ & 0.694 \\
\hline $10 \mathrm{R} / 7 \mathrm{R}$ & 1 & 2.94 & 2 & 3.39 & $0.864(0.075-9.893)$ & 0.906 \\
\hline $9 \mathrm{R} / 7 \mathrm{R}$ & 0 & 0 & 1 & 1.69 & $0.565(0.022-14.263)$ & 0.304 \\
\hline Homozygosity & 10 & 29.41 & 29 & 49.15 & $0.431(0.176-1.057)$ & 0.066 \\
\hline Heterozygosity & 24 & 70.59 & 30 & 50.85 & $2.320(0.946-5.690)$ & 0.066 \\
\hline Total & $34^{* *}$ & 100.0 & $59^{* *}$ & 100.0 & - & - \\
\hline
\end{tabular}

${ }^{*} \mathrm{CI}$ - confidence interval. ${ }^{* *}$ Analyzed patient numbers are lower than group totals as genotyping failed in some cases. Additional genotype groupings are italicized.

defining either normal or reduced COMT activity. None of the observed minor differences in genotype frequencies reached statistical significance.

\section{DRD4 gene}

The dopamine receptor gene DRD4 is being intensively studied with regard to its possible involvement in several mental disorders, such as attention deficit disorder (ADHD), gambling addiction, alcoholism, drug addiction, and schizophrenia $[30,38]$. The sequence of this gene contains a variable number of $48 \mathrm{bp}$ tandem repeats (VNTR) in the third exon, ranging from 2 to 11 repeats ( $2 \mathrm{R}$ to $11 \mathrm{R}$ ). The $4 \mathrm{R}$ allele is the most common in many populations, while the frequencies of the $2 \mathrm{R}$ and $7 \mathrm{R}$ alleles vary widely [39]. Test results for this polymorphism are shown in Table 5, which demonstrates that the presence of homozygosity at this VNTR locus, especially the $2 \mathrm{R} / 2 \mathrm{R}$ genotype $(\mathrm{OR}=0.218)$ appeared to be associated with a better prognosis, whereas the heterozygosity tends to be overrepresented in PC patients with a poorer prognosis $(\mathrm{OR}=2.333)$. Unfortunately, the number of analyzed cases was very low due to technical problems, and the differences between the groups were not statistically significant.

The $-521 \mathrm{C} / \mathrm{T}$ polymorphism in the promoter region of the $D R D 4$ gene influences its transcription level (decreased by $40 \%$ in $\mathrm{T} / \mathrm{T}$ homozygotes) [40], and the presence of the $\mathrm{C}$ allele was previously shown to be associated with schizophrenia development risk [38, 40], whereas the $\mathrm{T}$ allele was found to predispose to heroin addiction [41]. Table 6 presents the results that show a non-significant trend for the presence of the $\mathrm{C}$ allele at the locus to be associated with a more favorable $\mathrm{PC}$ prognosis.

\section{DISCUSSION}

The small pilot study described in this paper tentatively suggests that there may be an association between a few polymorphic variants of genes controlling neurotransmitter metabolism and the prognosis of PC. This previously unexplored association is especially intriguing as all the four polymorphic genes included in the analysis are known to modulate the predisposition to a range of neuropsychiatric disorders [28-35, 37, 38].

We believe that the most interesting results within our study were obtained for the STin2 polymorphism of the serotonin transporter gene SLC6A4. It is well documented that disturbances in the serotonin-controlled neuromodulation system involving the serotonin transporter are implicated in the pathogenesis of many behavioral disorders (anxiety, depression, obsessive compulsive disorder, aggression, addiction, suicide) as well as in major psychiatric conditions, such as bipolar disorder and schizophrenia [42, 43]. Regarding the SLC6A4 gene, the homozygous genotype $12 \mathrm{R} / 12 \mathrm{R}$ at the STin2 polymorphic locus was repeatedly reported to be linked with a predisposition to schizophrenia development $[42,44]$, whereas the $12 \mathrm{R} / 10 \mathrm{R}$ heterozygosity appeared to be protective [44]. Interestingly, our results show that $\mathrm{PC}$ patients with an unfavorable disease prognosis tend to have the $12 \mathrm{R} / 10 \mathrm{R}$ genotype more often $(\mathrm{OR}=$ $2.278 ; 95 \% \mathrm{CI}=0.953-5.444)$. Conversely, the $12 \mathrm{R} / 12 \mathrm{R}$ genotype and the homozygosity for the locus (comprising the $12 \mathrm{R} / 12 \mathrm{R}$ and $10 \mathrm{R} / 10 \mathrm{R}$ genotypes) appeared to be associated with a better $\mathrm{PC}$ prognosis $(\mathrm{OR}=0.431 ; 95 \%$ $\mathrm{CI}=0.176-1.057$ for all homozygotes). Although our 
Table 3: Genotype frequencies for the $M A O A-\mu V N T R 30$ bp polymorphism of the $M A O A$ in groups of PC patients defined as 'polar opposites' prognostically

\begin{tabular}{|c|c|c|c|c|c|c|}
\hline \multirow{3}{*}{$\begin{array}{c}\text { Polymorphism } \\
M A O A-\mu V N T R \\
30 \mathrm{bp}, \\
\text { number of repeats }\end{array}$} & \multicolumn{4}{|c|}{ Disease prognosis (according to PSADT) } & \multirow{3}{*}{ OR $\left(95 \% \mathrm{CI}^{*}\right)$} & \multirow{3}{*}{$P$-value } \\
\hline & \multicolumn{2}{|c|}{$\begin{array}{c}\text { Unfavorable } \\
\text { (low PSADT) }\end{array}$} & \multicolumn{2}{|c|}{$\begin{array}{c}\text { Favorable } \\
\text { (high PSADT) }\end{array}$} & & \\
\hline & $n$ & $\%$ & $n$ & $\%$ & & \\
\hline $4 \mathrm{R}$ & 16 & 55.17 & 37 & 66.07 & $0.632(0.252-1.582)$ & 0.327 \\
\hline $3 \mathrm{R}$ & 13 & 44.83 & 19 & 33.93 & $1.582(0.632-3.960)$ & 0.327 \\
\hline Total & $29^{* *}$ & 100.0 & $56^{* *}$ & 100.0 & - & - \\
\hline
\end{tabular}

${ }^{*} \mathrm{CI}$ - confidence interval. ${ }^{* *}$ Analyzed patient numbers are lower than group totals as genotyping failed in some cases.

Table 4: Genotype frequencies for the Val158Met polymorphism of the COMT gene in groups of PC patients defined as 'polar opposites' prognostically

\begin{tabular}{|c|c|c|c|c|c|c|}
\hline \multirow{3}{*}{$\begin{array}{l}\text { Polymorphism } \\
\text { COMT } \\
\text { Val158Met }\end{array}$} & \multicolumn{4}{|c|}{ Disease prognosis (according to PSADT) } & \multirow{3}{*}{ OR $\left(95 \% \mathrm{CI}^{*}\right)$} & \multirow{3}{*}{$P$-value } \\
\hline & \multicolumn{2}{|c|}{$\begin{array}{c}\text { Unfavorable } \\
\text { (low PSADT) }\end{array}$} & \multicolumn{2}{|c|}{$\begin{array}{c}\text { Favorable } \\
\text { (high PSADT) }\end{array}$} & & \\
\hline & $n$ & $\%$ & $n$ & $\%$ & & \\
\hline $\mathrm{G} / \mathrm{G}$ & 3 & 12.5 & 11 & 21.57 & $0.519(0.130-2.068)$ & 0.353 \\
\hline $\mathrm{G} / \mathrm{A}$ & 15 & 62.5 & 27 & 52.94 & $1.481(0.549-3.997)$ & 0.438 \\
\hline $\begin{array}{l}\text { A/A (reduced } \\
\text { COMT activity) }\end{array}$ & 6 & 25.0 & 13 & 25.49 & $0.974(0.318-2.981)$ & 0.964 \\
\hline G/G or G/A (normal COMT activity) & 18 & 75.0 & 38 & 74.5 & $1.026(0.335-3.140)$ & 0.964 \\
\hline Homozygosity & 9 & 37.5 & 24 & 47.06 & $0.675(0.250-1.821)$ & 0.438 \\
\hline Total & $24^{* *}$ & 100.0 & $51^{* *}$ & 100.0 & - & - \\
\hline
\end{tabular}

${ }^{*} \mathrm{CI}$ - confidence interval. ${ }^{* *}$ Analyzed patient numbers are lower than group totals as genotyping failed in some cases. Additional genotype groupings are italicized.

results were marginally non-significant statistically due to limited numbers of analyzed cases, these observations are perfectly in line with earlier communications reporting a decreased risk of developing PC amongst schizophrenia patients [16-18]. Indeed, the reported overrepresentation of the $12 \mathrm{R} / 12 \mathrm{R}$ genotype in schizophrenia patients [44] may possibly create a 'PC-protective genetic background' explaining a reduced $\mathrm{PC}$ incidence in men suffering from this psychiatric condition.

The results obtained for the other polymorphisms assessed in this study were in general inconclusive, but a few observations deserve to be noted. Monoamine oxidase A (MAOA) encoded by the MAOA gene is another enzyme involved in serotonin catabolism, and the $30 \mathrm{bp}$ VNTR in the promoter region of this gene is functionally important as the presence of its allele with four repeats elevates MAOA gene transcription level resulting in an increased enzyme activity $[33,45]$. Studies by other authors indicated that the lack of MAOA activity caused by the presence of the VNTR allele with three repeats is often associated with an increased risk of aggressivity and antisocial behavior [34]. Our results show that the same allele tends to be slightly overrepresented in PC patients with unfavorable disease prognosis, however the association failed to reach statistical significance. This result is not surprising as no influence of the major $M A O A-\mu V N T R$ variants on PC risk or prognosis could be found by a properly powered study of White et al. [46].

The COMT is one of the enzymes regulating the central dopamine function. The presence of the MET ${ }^{158}$ allele of the COMT gene reduces COMT enzyme activity and was previously reported both to predispose to psychiatric conditions [33-35] and to be possibly implicated in cancer risk modulation [47]. However, the outcome of our study has not revealed any significant effect of this COMT polymorphism on PC prognosis. This negative finding corroborates results previously published by other authors [48].

The $\mathrm{D}_{4}$ dopamine receptor encoded by the $D R D 4$ gene, which is highly polymorphic, is one of $\mathrm{D}_{2}$-like transmembrane dopamine receptors controlling the G-protein-mediated signaling pathway through adenylylcyclase inhibition [49]. The two DRD4 polymorphisms analyzed in our study were repeatedly shown to be associated with a range of psychiatric disorders [30, 38], but there was no pre-existing information on possible links between these gene variants and cancer. According to previously published reports, the DRD4 VNTR variants 
Table 5: Genotype frequencies for the DRD4 gene VNTR 48 bp polymorphism in groups of PC patients defined as 'polar opposites' prognostically

\begin{tabular}{|c|c|c|c|c|c|c|}
\hline \multirow{3}{*}{$\begin{array}{c}\text { Polymorphism } \\
\text { DRD } 4 \\
\text { VNTR } 48 \text { bp, } \\
\text { number of } \\
\text { repeats }\end{array}$} & \multicolumn{4}{|c|}{ Disease prognosis (according to PSADT) } & \multirow{3}{*}{ OR $\left(95 \% \mathrm{CI}^{*}\right)$} & \multirow{3}{*}{$P$-value } \\
\hline & \multicolumn{2}{|c|}{$\begin{array}{c}\text { Unfavorable } \\
\text { (low PSADT) }\end{array}$} & \multicolumn{2}{|c|}{$\begin{array}{c}\text { Favorable } \\
\text { (high PSADT) }\end{array}$} & & \\
\hline & $n$ & $\%$ & $n$ & $\%$ & & \\
\hline $2 \mathrm{R} / 2 \mathrm{R}$ & 1 & 5.0 & 7 & 19.44 & $0.218(0.025-1.917)$ & 0.170 \\
\hline $2 \mathrm{R} / 4 \mathrm{R}$ & 4 & 20.0 & 2 & 5.56 & $4.250(0.704-25.670)$ & 0.115 \\
\hline $3 R / 3 R$ & 2 & 10.0 & 2 & 5.56 & $1.889(0.245-14.550)$ & 0.541 \\
\hline $3 \mathrm{R} / 4 \mathrm{R}$ & 0 & 0 & 1 & 2.78 & $0.577(0.022-14.835)$ & 0.740 \\
\hline $4 \mathrm{R} / 4 \mathrm{R}$ & 8 & 40.0 & 17 & 47.22 & $0.745(0.246-2.257)$ & 0.603 \\
\hline $4 \mathrm{R} / 5 \mathrm{R}$ & 2 & 10.0 & 2 & 5.56 & $1.889(0.245-14.550)$ & 0.541 \\
\hline $4 \mathrm{R} / 6 \mathrm{R}$ & 2 & 10.0 & 2 & 5.56 & $1.889(0.245-14.550)$ & 0.541 \\
\hline $4 \mathrm{R} / 7 \mathrm{R}$ & 0 & 0 & 1 & 2.78 & $0.577(0.022-14.893)$ & 0.740 \\
\hline $6 \mathrm{R} / 6 \mathrm{R}$ & 1 & 5.0 & 2 & 5.56 & $0.895(0.076-10.528)$ & 0.929 \\
\hline Homozygosity & 12 & 60.0 & 28 & 77.8 & $0.429(0.130-1.410)$ & 0.163 \\
\hline Heterozygosity & 8 & 40.0 & 8 & 22.2 & $2.333(0.709-7.675)$ & 0.163 \\
\hline Total & $20^{* *}$ & 100.0 & $36^{* *}$ & 100.0 & - & - \\
\hline
\end{tabular}

${ }^{*} \mathrm{CI}$ - confidence interval. ${ }^{* *}$ Indicated numbers of analyzed patients differ from group totals as genotyping failed in some cases. Additional genotype groupings are italicized.

with a higher number of repeats tended to predispose to depression and other mental disorders [30]. It is remarkable that among our patients, the genotype $2 \mathrm{R} / 2 \mathrm{R}$ with the lowest number of repeats appeared to be linked with a better PC prognosis $(\mathrm{OR}=0.218 ; 95 \% \mathrm{CI}=0.025-1.917)$, but the difference failed to reach statistical significance. Likewise, the presence of the homozygosity at this VNTR locus tended to be protective, whereas the heterozygosity was slightly overrepresented among PC patients with unfavorable prognosis (see Table 5). Another DRD4 gene variant demonstrating a weak association with a better $\mathrm{PC}$ prognosis was the presence of the $\mathrm{C}$ allele at position -521 of DRD4 gene promoter. Although this association was not statistically significant, it is noteworthy that the same allele is associated with an increased risk of developing schizophrenia [38, 40]. Therefore, its presence may potentially contribute to the 'PC-protective genetic background' probably existing in patients with schizophrenia and discussed above in relation to the SLC6A4 gene STin2 polymorphism.

It should be accepted that this small pilot study had serious limitations. Small study size restricted its statistical power, and technical problems that in most cases could be attributed to DNA degradation during long-term sample storage, further limited the number of successfully performed tests. For this reason, it was difficult to expect obtaining statistically significant differences between genotypedefined subgroups and results often looked inconclusive. Nevertheless, some interesting trends could be revealed, especially those probably related to the inverse relationship between risks of developing schizophrenia and PC.
Oncological conditions are known to occur less frequently in schizophrenia patients [11,13-16], and this phenomenon primarily affects men [50], being especially pronounced for PC [13, 16-18]. Interestingly, PC has recently emerged as a cancer, development of which strongly depends on neurogenic regulatory pathways provided by nerves growing as an important TME component [51]. It is also notable that schizophrenia-related alterations in neurotransmitter-modulated tumor angiogenesis were recently hypothesized to be a factor reducing neoplasia development risk in this group of patients [52]. Furthermore, neurotransmitters, such as serotonin and dopamine, are now regarded as major factors modulating neoplastic growth through influences on angiogenesis and neoplastic cell proliferation [53]. The results presented in this paper indicate that the presence of certain polymorphic variants of the SLC6A4 and DRD4 genes related to serotonin and dopamine signaling pathways respectively appears to correlate with PC prognosis. Although our findings remain inconclusive, these preliminary observations deserve to be explored in depth. Further larger studies are needed for clarifying the role of neurotransmitter metabolism gene polymorphisms in PC pathogenesis.

\section{MATERIALS AND METHODS}

\section{Selection of PC patients for genotyping}

This study was designed with the aim of comparing selected polymorphic gene variant presence in PC patients 


\section{Table 6: Genotype frequencies for the $-521 \mathrm{C} / \mathrm{T}$ DRD4 gene polymorphism in groups of PC patients defined as 'polar opposites' prognostically}

\begin{tabular}{|c|c|c|c|c|c|c|}
\hline \multirow{3}{*}{$\begin{array}{l}\text { Polymorphism } \\
\text { DRD } 4 \\
-521 \text { C/T }\end{array}$} & \multicolumn{4}{|c|}{$\begin{array}{c}\text { Disease prognosis } \\
\text { (according to PSADT) }\end{array}$} & \multirow{3}{*}{ OR $\left(95 \% \mathrm{CI}^{*}\right)$} & \multirow{3}{*}{$P$-value } \\
\hline & \multicolumn{2}{|c|}{$\begin{array}{l}\text { Unfavorable } \\
\text { (low PSADT) }\end{array}$} & \multicolumn{2}{|c|}{$\begin{array}{c}\text { Favorable } \\
\text { (high PSADT) }\end{array}$} & & \\
\hline & $n$ & $\%$ & $n$ & $\%$ & & \\
\hline $\mathrm{C} / \mathrm{C}$ & 4 & 12.9 & 10 & 16.13 & $0.770(0.221-2.687)$ & 0.682 \\
\hline $\mathrm{C} / \mathrm{T}$ & 11 & 35.48 & 27 & 43.55 & $0.713(0.293-1.737)$ & 0.457 \\
\hline $\mathrm{T} / \mathrm{T}$ (reduced gene transcription) & 16 & 51.61 & 25 & 40.32 & $1.579(0.663-3.761)$ & 0.303 \\
\hline$C / C$ or $C / T$ (normal gene transcription) & 15 & 48.39 & 37 & 59.68 & $0.633(0.266-1.509)$ & 0.303 \\
\hline Homozygosity & 20 & 67.74 & 35 & 56.45 & $1.403(0.576-3.418)$ & 0.457 \\
\hline Total & $31^{* *}$ & 100.0 & $62^{* *}$ & 100.0 & - & - \\
\hline
\end{tabular}

${ }^{*} \mathrm{CI}$ - confidence interval. ${ }^{* *}$ Indicated numbers of analyzed patients differ from group totals as genotyping failed in some cases. Additional genotype groupings are italicized.

with either very favorable or utterly unfavorable variants (i. e. 'polar opposites') of disease prognosis defined by PSADT values measured before treatment initiation. The PSADT was calculated using an online calculator, in accordance with the accepted recommendations of the Memorial Sloan Kettering Cancer Center [54]. Prognostically favorable cases $(N=67)$ were defined by the PSADT values exceeding 30 months, while a prerequisite for inclusion was a PSA history of at least one year. In some of these patients, the PSADT values could not be determined as there was no PSA concentration increase throughout the observation period. In contrast, cases where the PSADT values did not exceed two months $(N=40)$ were regarded as prognostically unfavorable.

\section{Genotyping}

The most significant polymorphisms in four genes encoding regulatory proteins controlling neurotransmitter metabolism were selected for the study: the serotonin transporter gene (SLC6A4), the catechol-orthomethyltransferase gene (COMT), the monoamine oxidase A gene (MAOA), the dopamine receptor gene (DRD4). All these genes are known to be associated with mental disorders: schizophrenia, depression, deviant behavior. The distribution of gene polymorphisms was assessed and compared in two groups of patients with PC characterized as 'polar opposites' in terms of disease prognosis.

Genomic DNA was extracted from peripheral blood cells using the reagent kit "DNA-Extran-1", (Syntol, Russia) in accordance with the manufacturer's instructions. The isolated DNA was used for the detection of the selected gene polymorphisms by PCR.

Determination of polymorphism in STin2 VNTR of the SLC6A4 gene was carried out using the method of polymerase chain reaction (PCR). The reagent kit "Encyclo Plus PCR kit" and a pair of sequence-specific primers were employed. The primers synthesized by
Eurogen (Russia) had the following sequences:

F 5'- CAATGTCTGGCGCTTCCCCTACATAT - $3^{\prime}$

R 5'-GACATAATCTGTCTTCTGGCCTCTCAAG - $3^{\prime}$

The following PCR conditions were applied for the detection of the STin2 VNTR: Initial denaturation at $95^{\circ} \mathrm{C}$ for 4 min was followed by 31 three-step cycles that comprised denaturation for 30 seconds at $95^{\circ} \mathrm{C}$, annealing for 30 seconds at $67^{\circ} \mathrm{C}$, and extension for 40 seconds at $72^{\circ} \mathrm{C}$. At the last stage, the final extension step was performed at $72^{\circ} \mathrm{C}$ for 5 minutes.

PCR results were assessed using DNA gel electrophoresis in $12 \%$ polyacrylamide gel, followed by staining with SYBR Green I (Lumiprobe, Russia) and visualization of the fragments in transmitted with 100 bp DNA ladder (SibEnzyme, Russia) used for fragment length determination.

The amplified fragments were distributed as follows: 222 bp - 9 repeats, 261 bp - 10 repeats, 300 bp 12 repeats.

The PCR used for the determination of MAOA$\mu V N T R$ polymorphism was carried out using the reagent kit "Encyclo Plus PCR kit" and a pair of primers synthesized by Eurogen (Russia).

F 5'-ACAGCCTGACCGTGGAGAAG-3'

R 5'-GAACGGACGCTCCATTCGGA-3'

The following PCR conditions were applied for the detection of the MAOA- $\mu V N T R$ :

Initial denaturation at $95^{\circ} \mathrm{C}$ for $3 \mathrm{~min}$ was followed by 30 three-step cycles that comprised denaturation for 30 seconds at $95^{\circ} \mathrm{C}$, annealing for 30 seconds at $60^{\circ} \mathrm{C}$, and extension for 40 seconds at $72^{\circ} \mathrm{C}$. At the last stage, the final extension step was performed at $72^{\circ} \mathrm{C}$ for 5 minutes.

The method used for PCR result visualization did not differ from that used for STin2 VNTR and described above. The amplified fragments were distributed as follows:

291 bp - 2 repeats, 321 bp - 3 repeats, 336 bp - 3.5 repeats, $351 \mathrm{bp}-4$ repeats, $381 \mathrm{bp}-5$ repeats. 
To analyze the polymorphic Val158Met locus (472A $>\mathrm{G}$, rs 4680$)$ of the $C O M T$ gene and the DRD4 locus rs1800955 (-521 C/T promoter polymorphism), we used the SNP-express-RV reagent kits (Litekh, Russia) and SNPScreen (Syntol, Russia), respectively, by real-time PCR using CFX96 Touch ${ }^{\mathrm{TM}}$ Real-Time PCR Detection System (BioRad, USA) according to the manufacturer's instructions.

Determination of DRD4 polymorphism (VNTR 48bp) was carried out using the "TAPOTILI - locus DRD4-VNTR" reagent kit (TAPOTILI company, Russia) by real -time PCR using CFX96 Touch $^{\mathrm{TM}}$ Real-Time PCR Detection System (Bio-Rad, USA) according to the manufacturer's instructions.

\section{Author contributions}

Concept and design, study supervision: Gennady Zharinov, Sergei Khalchitsky; development of methodology, acquiring and managing patients, analysis and interpretation of data (e.g., statistical analysis, biostatistics, computational analysis): Gennady Zharinov, Sergei Khalchitsky, Marina Sogoyan, Yulia Khutoryanskaya, Natalia Neklasova, Oleg Bogomolov, Ilya Smirnov, Marina Samoilovich, Vladimir Skakun; literature search, writing, review, and/or revision of the manuscript: Alexandre Loktionov, Oleg Bogomolov, Sergei Vissarionov, Vladimir Anisimov.

\section{CONFLICTS OF INTEREST}

Authors have no conflicts of interest to declare.

\section{FUNDING}

This study was supported in part by funding from The Russian Ministry of Health.

\section{REFERENCES}

1. Hanahan D, Weinberg RA. The hallmarks of cancer. Cell. 2000; 100:57-70. https://doi.org/10.1016/s00928674(00)81683-9. [PubMed]

2. Hanahan D, Weinberg RA. Hallmarks of cancer: the next generation. Cell. 2011; 144:646-674. https://doi. org/10.1016/j.cell.2011.02.013. [PubMed]

3. Maman S, Witz IP. A history of exploring cancer in context. Nat Rev Cancer. 2018; 18:359-376. https://doi.org/10.1038/ s41568-018-0006-7. [PubMed]

4. Hinshaw DC, Shevde LA. The tumor microenvironment innately modulates cancer progression. Cancer Res. 2019; 79:4557-4566. https://doi.org/10.1158/0008-5472.CAN-183962. [PubMed]

5. Greten FR, Grivennikov SI. Inflammation and cancer: triggers, mechanisms, and consequences. Immunity. 2019; 51:27-41. https://doi.org/10.1016/j.immuni.2019.06.025. [PubMed]
6. Kreuzaler P, Panina Y, Segal J, Yuneva M. Adapt and conquer: Metabolic flexibility in cancer growth, invasion and evasion. Mol Metab. 2020; 33:83-101. https://doi. org/10.1016/j.molmet.2019.08.021. [PubMed]

7. Jones JO, Moody WM, Shields JD. Microenvironmental modulation of the developing tumour: an immunestromal dialogue. Mol Oncol. 2020 Aug 2. https://doi. org/10.1002/1878-0261.12773. [Epub ahead of print]. [PubMed]

8. Laplane L, Duluc D, Bikfalvi A, Larmonier N, Pradeu T. Beyond the tumour environment. Int J Cancer. 2019; 145:2611-2618. https://doi.org/10.1002/ijc.32343. [PubMed]

9. Loktionov A. Common gene polymorphisms and nutrition: emerging links with pathogenesis of multifactorial chronic diseases (review). J Nutr Biochem. 2003; 14:426-451. https://doi.org/10.1016/s0955-2863(03)00032-9. [PubMed]

10. Loktionov A. Common gene polymorphisms, cancer progression and prognosis. Cancer Lett. 2004; 208:1-33. https://doi.org/10.1016/j.canlet.2004.02.009. [PubMed]

11. Reiche EM, Nunes SO, Morimoto HK. Stress, depression, the immune system, and cancer. Lancet Oncol. 2004; 5:617-625. https://doi.org/10.1016/S1470-2045(04)01597-9. [PubMed]

12. Osborn DP, Limburg H, Walters K, Petersen I, King M, Green J, Watson J, Nazareth I. Relative incidence of common cancers in people with severe mental illness. Cohort study in the United Kingdom THIN primary care database. Schizophr Res. 2013; 143:44-49. https://doi. org/10.1016/j.schres.2012.11.009. [PubMed]

13. Ji J, Sundquist K, Ning Y, Kendler KS, Sundquist J, Chen $\mathrm{X}$. Incidence of cancer in patients with schizophrenia and their first-degree relatives: a population-based study in Sweden. Schizophr Bull. 2013; 39:527-536. https://doi. org $/ 10.1093 / \mathrm{schbul} / \mathrm{sbs} 065$. [PubMed]

14. Currier MB, Nemeroff CB. Depression as a risk factor for cancer: from pathophysiological advances to treatment implications. Annu Rev Med. 2014; 65:203-221. https:// doi.org/10.1146/annurev-med-061212-171507. [PubMed]

15. Zhang Z, Wang Y, Li Q. Mechanisms underlying the effects of stress on tumorigenesis and metastasis (Review). Int J Oncol. 2018; 53:2332-2342. https://doi.org/10.3892/ ijo.2018.4570. [PubMed]

16. Li H, Li J, Yu X, Zheng H, Sun X, Lu Y, Zhang Y, Li C, Bi X. The incidence rate of cancer in patients with schizophrenia: A meta-analysis of cohort studies. Schizophr Res. 2018; 195:519528. https://doi.org/10.1016/j.schres.2017.08.065. [PubMed]

17. Torrey EF. Prostate cancer and schizophrenia. Urology. 2006; 68:1280-1283. $\quad$ https://doi.org/10.1016/j. urology.2006.08.1061. [PubMed]

18. Raviv G, Laufer M, Baruch Y, Barak Y. Risk of prostate cancer in patients with schizophrenia. Compr Psychiatry. 2014; 55:1639-1642. https://doi.org/10.1016/j. comppsych.2014.05.007. [PubMed]

19. Ferlay J, Colombet M, Soerjomataram I, Mathers C, Parkin DM, Pineros M, Znaor A, Bray F. Estimating the global 
cancer incidence and mortality in 2018: GLOBOCAN sources and methods. Int J Cancer. 2019; 144:1941-1953. https://doi.org/10.1002/ijc.31937. [PubMed]

20. Sathianathen NJ, Konety BR, Crook J, Saad F, Lawrentschuk N. Landmarks in prostate cancer. Nat Rev Urol. 2018; 15:627-642. https://doi.org/10.1038/s41585018-0060-7. [PubMed]

21. Ramírez ML, Nelson EC, Devere White RW, Lara PN Jr, Evans CP. Current Applications for Prostate-Specific Antigen Doubling Time. Eur Urol. 2008; 54:291-302. https://doi.org/10.1016/j.eururo.2008.04.003. [PubMed]

22. Keizman D, Huang P, Antonarakis ES, Sinibaldi V, Carducci MA, Denmeade S, Kim JJ, Walczak J, Eisenberger MA. The change of PSA doubling time and its association with disease progression in patients with biochemically relapsed prostate cancer treated with intermittent androgen deprivation. Prostate. 2011; 71:1608-1615. https://doi. org/10.1002/pros.21377. [PubMed]

23. Crawford ED, Bennett CL, Andriole GL, Garnick MB, Petrylak DP. The utility of prostate-specific antigen in the management of advanced prostate cancer. BJU Int. 2013; 112:548-560. https://doi.org/10.1111/bju.12061. [PubMed]

24. Zharinov GM, Bogomolov OA, Neklasova NN, Anisimov VN. Pretreatment prostate specific antigen doubling time as prognostic factor in prostate cancer patients. Oncoscience. 2017; 4:7-13. https://doi.org/10.18632/oncoscience.337. [PubMed]

25. Duffy MJ. Biomarkers for prostate cancer: prostate-specific antigen and beyond. Clin Chem Lab Med. 2020; 58:326339. https://doi.org/10.1515/cclm-2019-0693. [PubMed]

26. Zharinov GM. Database of patients with prostate cancer. Certificate of registration of the database No. 2016620331. Application No. 2015621209. Date of receipt 01 October 2015. Date of state registration in the Registry of databases March 14, 2016 [Article in Russian].

27. Nikolaeva AV, Malkova EE, Zharinov GM. [Differences in clinical and psychological characteristics of the personality of patients with prostate cancer at high and low rates of tumor growth]. [Article in Russian]. Radiation Diagnostics and Therapy. 2017; 3:132-133.

28. Nordquist N, Oreland L. Serotonin, genetic variability, behavior, and psychiatric disorders - a review. Ups J Med Sci. 2010; 115:2-10. https://doi. org/10.3109/03009730903573246. [ [ $\underline{\text { PubMed] }}$

29. Margoob MA, Mushtaq D. Serotonin transporter gene polymorphism and psychiatric disorders: Is there a link? Indian J Psychiatry. 2011; 53:289-299. https://doi. org/10.4103/0019-5545.91901. [PubMed]

30. Ptácek R, Kuzelová H, Stefano GB. Dopamine D4 receptor gene DRD4 and its association with psychiatric disorders. Med Sci Monit. 2011; 17:RA215-RA220. https://doi. org $/ 10.12659 / \mathrm{msm} .881925$. [PubMed]

31. Mirkovic B, Laurent C, Podlipski MA, Frebourg T, Cohen D, Gerardin P. Genetic association studies of suicidal behavior: a review of the past 10 years, progress, limitations and future directions. Front Psychiatry. 2016; 7:158. https:// doi.org/10.3389/fpsyt.2016.00158. [PubMed]

32. Devor A, Andreassen OA, Wang Y, Mäki-Marttunen T, Smeland OB, Fan CC, Schork AJ, Holland D, Thompson WK, Witoelar A, Chen CH, Desikan RS, McEvoy LK, et al. Genetic evidence for role of integration of fast and slow neurotransmission in schizophrenia. Mol Psychiatry. 2017; 22:792-801. https://doi.org/10.1038/mp.2017.33. [PubMed]

33. Sabol SZ, Hu S, Hamer D. A functional polymorphism in the monoamine oxidase A gene promoter. Hum Genet. 1998; 103:273-279. https://doi.org/10.1007/s004390050816. [PubMed]

34. Kolla NJ, Bortolato $\mathrm{M}$. The role of monoamine oxidase A in the neurobiology of aggressive, antisocial, and violent behavior: A tale of mice and men. Prog Neurobiol. 2020; 194:101875. https://doi.org/10.1016/j. pneurobio.2020.101875. [PubMed]

35. Witte AV, Flöel A. Effects of COMT polymorphisms on brain function and behavior in health and disease. Brain Res Bull. 2012; 88:418-428. https://doi.org/10.1016/j. brainresbull.2011.11.012. [PubMed]

36. Taylor S. Association between COMT Val158Met and psychiatric disorders: A comprehensive meta-analysis. Am J Med Genet B Neuropsychiatr Genet. 2018; 177:199-210. https://doi.org/10.1002/ajmg.b.32556. [PubMed]

37. Kumar P, Rai V. Catechol-O-methyltransferase gene Val158Met polymorphism and obsessive compulsive disorder susceptibility: a meta-analysis. Metab Brain Dis. 2020; 35:241-251. https://doi.org/10.1007/s11011-01900495-0. [PubMed]

38. Xu FL, Wu X, Zhang JJ, Wang BL, Yao J. A meta-analysis of data associating DRD4 gene polymorphisms with schizophrenia. Neuropsychiatr Dis Treat. 2018; 14:153164. https://doi.org/10.2147/NDT.S156479. [PubMed]

39. Lichter JB, Barr CL, Kennedy JL, van Tol HH, Kidd KK, Livak KJ. A hypervariable segment in the human dopamine receptor D4 (DRD4) gene. Hum Mol Genet. 1993; 2:76773. https://doi.org/10.1093/hmg/2.6.767. [PubMed]

40. Okuyama Y, Ishiguro H, Toru M, Arinami T. A genetic polymorphism in the promoter region of $\mathrm{DRD}_{4}$ associated with expression and schizophrenia. Biochem Biophys Res Commun. 1999; 258:292-295. https://doi.org/10.1006/ bbrc.1999.0630. [PubMed]

41. Lai JH, Zhu YS, Huo ZH, Sun RF, Yu B, Wang YP, Chai $\mathrm{ZQ}$, Li SB. Association study of polymorphisms in the promoter region of DRD4 with schizophrenia, depression, and heroin addiction. Brain Res. 2010; 1359:227-232. https://doi.org/10.1016/j.brainres.2010.08.064. [PubMed]

42. Haddley K, Bubb VJ, Breen G, Parades-Esquivel UM, Quinn JP. Behavioural genetics of the serotonin transporter. Curr Top Behav Neurosci. 2012; 12:503-535. https://doi. org/10.1007/7854_2011_186. [PubMed]

43. Baou M, Boumba V, Petrikis P, Rallis G, Vougiouklakis T, Mavreas $\mathrm{V}$. A review of genetic alterations in the serotonin 
pathway and their correlation with psychotic diseases and response to atypical antipsychotics. Schizophr Res. 2016; 170:18-29. https://doi.org/10.1016/j.schres.2015.11.003. [PubMed]

44. Xu F, Wang B, Yao J. Association between the SLC6A4 gene and schizophrenia: an updated meta-analysis. Neuropsychiatr Dis Treat. 2019; 15:143-155. https://doi. org/10.2147/NDT.S190563. [PubMed]

45. Matsusue A, Kibo SI, Ikeda $\mathrm{T}$, Tani N, Maeda $\mathrm{T}$, Kashiwagi M, Hara K, Waters B, Takayama M, Ikematsu $\mathrm{N}$, Ishikawa T. VNTR polymorphism in the monoamine oxidase A promoter region and cerebrospinal fluid catecholamine concentrations in forensic autopsy cases. Neurosci Lett. 2019; 701:71-76. https://doi.org/10.1016/j. neulet.2019.02.029. [PubMed]

46. White T, Kwon EM, Fu R, Lucas JM, Ostrander EA, Stanford JL, Nelson PS. The monoamine oxidase A gene promoter repeat and prostate cancer risk. Prostate. 2012; 72:16221627. https://doi.org/10.1002/pros.22515. [PubMed]

47. Sak K. The Val158Met polymorphism in COMT gene and cancer risk: role of endogenous and exogenous catechols. Drug Metab Rev. 2017; 49:56-83. https://doi.org/10.1080/ 03602532.2016.1258075. [PubMed]

48. Chen Y, Yu X, Li T, Yan H, Mo Z. Significant association of catechol-O-methyltransferase Val158Met polymorphism with bladder cancer instead of prostate and kidney cancer. Int J Biol Markers. 2016; 31:e110-e117. https://doi. org/10.5301/jbm.5000204. [PubMed]
49. Beaulieu JM, Espinosa S, Gainetdinov RR. Dopamine receptors - IUPHAR Review 13. Br J Pharmacol. 2015; 172:1-23. https://doi.org/10.1111/bph.12906. [PubMed]

50. Lin GM, Chen YJ, Kuo DJ, Jaiteh LES, Wu YC, Lo TS, Li YH. Cancer incidence in patients with schizophrenia or bipolar disorder: a nationwide population-based study in Taiwan, 1997-2009. Schizophr Bull. 2013; 39:407-416. https://doi.org/10.1093/schbul/sbr162. [PubMed]

51. Zahalka AH, Frenette PS. Nerves in cancer. Nat Rev Cancer. 2020; 20:143-157. https://doi.org/10.1038/s41568-0190237-2. [PubMed]

52. Lopes R, Soares R, Figueiredo-Braga M, Coelho R. Schizophrenia and cancer: Is angiogenesis a missed link? Life Sci. 2014; 97:91-95. https://doi.org/10.1016/j. 1fs.2013.12.023. [PubMed]

53. Peters MAM, Walenkamp AME, Kema IP, Meijer C, de Vries EGE, Oosting SF. Dopamine and serotonin regulate tumor behavior by affecting angiogenesis. Drug Resist Updat. 2014; 17:96-104. https://doi.org/10.1016/j. drup.2014.09.001. [PubMed]

54. Pound CR, Partin AW, Eisenberger MA, Chan DW, Pearson JD, Walsh PC. Natural history of progression after PSA elevation following radical prostatectomy. JAMA. 1999; 281:1591-1597. https://doi.org/10.1001/jama.281.17.1591. [PubMed] 